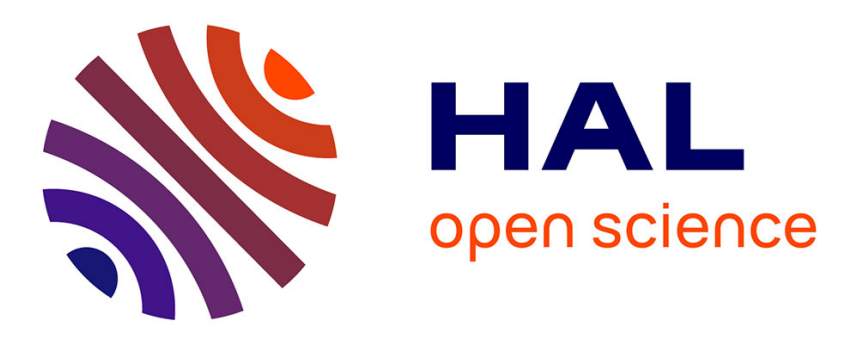

\title{
Insect herbivory and avian insectivory in novel native oak forests: Divergent effects of stand size and connectivity
}

Elena Valdés Correcher, Inge van Halder, Luc Barbaro, Bastien Castagneyrol, Arndt Hampe

\section{To cite this version:}

Elena Valdés Correcher, Inge van Halder, Luc Barbaro, Bastien Castagneyrol, Arndt Hampe. Insect herbivory and avian insectivory in novel native oak forests: Divergent effects of stand size and connectivity. Forest Ecology and Management, 2019, 445, pp.146-153. 10.1016/j.foreco.2019.05.018 . hal-02181063

\section{HAL Id: hal-02181063 \\ https://hal.science/hal-02181063}

Submitted on 22 Oct 2021

HAL is a multi-disciplinary open access archive for the deposit and dissemination of scientific research documents, whether they are published or not. The documents may come from teaching and research institutions in France or abroad, or from public or private research centers.
L'archive ouverte pluridisciplinaire $\mathbf{H A L}$, est destinée au dépôt et à la diffusion de documents scientifiques de niveau recherche, publiés ou non, émanant des établissements d'enseignement et de recherche français ou étrangers, des laboratoires publics ou privés.

\section{(ㅇ)(1) $\$$}

Distributed under a Creative Commons Attribution - NonCommerciall 4.0 International 


\section{Insect herbivory and avian insectivory in novel native oak forests: 2 divergent effects of stand size and connectivity}

3 Authors: Elena Valdés-Correcher ${ }^{1 *}$, Inge van Halder $^{1}$, Luc Barbaro ${ }^{2 \cdot 3}$, Bastien Castagneyrol ${ }^{1}$ \& Arndt

4 Hampe $^{1}$

\section{Affiliations:}

$6{ }^{1}$ BIOGECO, INRA, Univ. Bordeaux, 33610 Cestas, France

72 Dynafor, INRA-INPT, Univ. Toulouse, Auzeville, France

$8{ }^{3}$ CESCO, Muséum national d'Histoire naturelle, CNRS, Sorbonne-Univ., Paris, France

9 * Corresponding author : elena.valdes.correcher@ gmail.com 


\section{Abstract}

17 The value of novel native broadleaf woodlands for biodiversity conservation is important to 18 consider for adequate forest management in rural landscapes. Passive reforestation has been 19 proposed as a cost-efficient tool for creating networks of novel native forest stands that would help 20 restoring biodiversity and associated ecosystem services. Yet to date the ecological functioning of 21 such stands remains strongly understudied compared to forest remnants resulting from longer-term 22 fragmentation. We assessed how the size and connectivity of newly established Pedunculate oak 23 (Quercus robur L.) stands in rural landscapes of SW France affect rates of herbivory by different 24 insect guilds as well as rates of avian insectivory and the abundance and richness of insectivorous 25 birds. Comparing 18 novel forest stands along a gradient of size (0.04-1.15 ha) and cover of 26 broadleaf forests in the surroundings ( $0-30 \%$ within a $500 \mathrm{~m}$ radius), we found that even the smallest 27 stands are colonised by leaf miners and chewers/skeletonizers, and that rates of herbivory are 28 globally comparable to those reported from older and larger oak forests. The size of stands had a 29 relatively minor effect on herbivory, whereas it increased the abundance of insectivorous bird. It 30 also determined rates of avian insectivory as estimated by an experiment with plasticine 31 caterpillars. These rates were however rather low and unrelated with the extent of herbivory in the 32 stand. Overall, our study indicates that insect herbivores tend to react more rapidly to the 33 establishment of novel native forests than their avian predators as the latter may depend on the 34 development of larger patches of suitable habitat in the surrounding landscape. To favour a rapid 35 build-up of diverse, and hence stable, trophic networks involving insect herbivores and their 36 predators, woodland creation schemes should therefore primarily focus on habitat size and quality.

\section{Keywords}

38 Herbivory, Avian predation, Bird communities, Native oak forest, Connectivity, Afforestation 


\section{Introduction}

42 Forest fragmentation is well-known to alter patterns of species distribution and abundance, relationships 43 between organisms and resulting ecosystem processes (Ewers and Didham, 2006; Fahrig, 2017; Haddad et 44 al., 2015; Lindenmayer and Fisher, 2013). Among others, it exerts strong effects on trophic cascades such 45 as plant-herbivore-predator interactions, eventually affecting rates of tree damage and health (Bagchi et al., 46 2018; Chávez-Pesqueira et al., 2015; Rossetti et al., 2017). While forest fragmentation continues to occur 47 in many regions of the world, forest cover is increasing in many others as a consequence of active planting 48 and passive afforestation following rural abandonment (Fuchs et al., 2015; Hansen et al., 2013). For 49 instance, Europe has experienced a steady increase of forested surfaces by 0.8 million ha per year since 501990 (Forest Europe, 2015), a trend that is expected to continue in the coming decades (Fuchs et al., 2015; 51 Schröter et al., 2005). Habitat defragmentation through passive afforestation has been proposed as an

52 effective tool to reinforce biodiversity and ecosystem functioning in rural and urban landscapes where forest 53 stands were formerly sparse and isolated (Fischer et al., 2006; Rey Benayas et al., 2008; Rey Benayas and 54 Bullock, 2012). Yet little ecological research has to date focused on newly established native forest stands 55 and we largely ignore whether trophic interactions in such stands underlie similar mechanisms as in 56 remnants of similar sizes but resulting from forest fragmentation.

57 Novel native forest stands establish from a few founder trees that colonize an available habitat patch within 58 an unsuitable matrix through long-distance dispersal and fill their neighbourhood with their offsprings 59 (Gerzabek et al., 2017; Sezen et al., 2005). Such stands share certain characteristics that set them apart from 60 those created by fragmentation: (i) they typically are quite small-sized - even smaller than the smallest 61 fragments of remnant forest; (ii) they are dominated by young trees, resulting in a reduced amount and range 62 of habitats available to forest-dwelling species (Franklin, 1988; Fuller et al., 2018); and (iii) all their species 63 necessarily originate from colonization events over a limited period of time, implying that these systems are 64 triggered by immigration credit instead of extinction debt (Jackson and Sax, 2010). Recent studies on insect 65 and bird species richness along chronosequences of novel native forest development have shown that these 66 are rapidly colonized by woodland generalists whereas specialists can still remain absent even 150 years 67 after forest establishment (Fuentes-Montemayor et al., 2015; Fuller et al., 2018; Whytock et al., 2018). 68 These studies also revealed that local stand characteristics are relatively more important than landscape 69 characteristics for successful colonization by insects and birds. Similar findings have been reported for 70 planted forests (reviewed in Burton et al., 2018). However, their consequences for trophic relationships 71 between plants, insect herbivores and insectivores remain unknown.

72 Despite the differences between novel native forest stands and remnant forest fragments, the ecological 73 mechanisms underlying trophic cascades involving trees, insect herbivores and birds can to some extent be 
74 inferred from fragmentation studies. These have documented that the size and connectivity of forest stands 75 can shape trophic cascades very differently depending on the relative importance of the bottom-up and top76 down effects involved (De La Vega et al., 2012; Rossetti et al., 2014). Thus, small and isolated forest stands 77 provide less and possibly lower-quality resources to herbivores (Chávez-Pesqueira et al., 2015) and their 78 colonization requires longer-distance movements that increase energetic and fitness costs (O'Rourke and 79 Petersen, 2017), eventually resulting in lower herbivore abundance (De La Vega et al., 2012; Simonetti et 80 al., 2007). However, small stands also experience greater edge effects which typically go along with 81 increased herbivory (Bagchi et al., 2018; De Carvalho Guimarães et al., 2014). On the other hand, insect

82 herbivores are more likely to colonize small but closer novel forest stands while their predatory vertebrates 83 are more likely to colonize more distant but larger ones (Barbaro et al., 2014; Bereczki et al., 2014; Cooper 84 et al., 2012; Maguire et al., 2015).

85 There is broad consensus that, generally, predators can notably reduce insect herbivory by regulating 86 herbivore populations (Böhm et al., 2011; Letourneau et al., 2009; Maguire et al., 2015; Rosenheim, 1998).

87 However, their actual relevance in novel native forest stands depends strongly on how both prey and 88 predators respond to stand size and connectivity (Gripenberg and Roslin, 2007). This study investigated 89 how levels of insect herbivory, avian predation and the abundance and diversity of insectivorous birds in 90 recently established native Pedunculate oak (Quercus robur) forest stands are influenced by their size and 91 the cover of broadleaf forest in the surrounding landscape. Specifically, we addressed the following 92 questions: (i) Does herbivory increase or decrease along gradients of increasing stand size and connectivity? 93 (ii) Does avian predation increase or decrease along the same gradients? (iii) Are the observed trends related 94 with the local abundance and diversity of insectivorous birds? We contrast our findings with those reported 95 from studies of forest fragmentation and discuss implications in a context of increasing forest connectivity 96 following ongoing changes in landscape use and management (Burton et al., 2018; Rey Benayas and 97 Bullock, 2012).

\section{Material and methods}

\section{Study area and selection of study sites}

100 The study was carried out in the Landes de Gascogne region (south-western France) about $40 \mathrm{~km}$ southwest 101 of Bordeaux $\left(44^{\circ} 41^{\prime} \mathrm{N}, 00^{\circ} 51^{\prime} \mathrm{W}\right)$. The region is characterized by an oceanic climate with mean annual 102 temperature of $12.8^{\circ} \mathrm{C}$ and annual precipitation of $873 \mathrm{~mm}$ over the last 20 years. The area is covered by 103 extensive plantations of maritime pine (Pinus pinaster Ait.) interspersed with small stands of broadleaved 104 forests that are dominated by Pedunculate oak (Quercus robur L.) and contain Pyrenean oak (Quercus 
105 pyrenaica Willd.), birch (Betula pendula L.) and other tree species in minor abundance. Such stands are

106 largely exempt from forest management. Many are actively expanding (Gerzabek et al., 2017), favoured by

107 a recent change in silvicultural management that tends to conserve broadleaved trees recruiting within

108 adjacent pine plantations as a mean of conservation biological control (Castagneyrol et al., 2014; Dulaurent

109 et al., 2011).

110 We carefully selected a total of 18 novel oak forest stands along gradients of stand size and connectivity

111 (Fig. A1). To ensure that forest stands were of recent origin, we confirmed on aerial photographs from the

112 1950s that only very few trees were present at that time. We measured the stand area (henceforth referred to

113 as stand size) as the minimum polygon including all oak trees with a stem diameter at breast height of $\geq 3 \mathrm{~cm}$

114 (range: 0.04-1.15 ha; Table A1). The basal area of the stand was also measured and was highly correlated

115 with stand size so we decided to include only stand size in the analysis (Pearson $r=0.92, P<0.05$ ). We

116 quantified the spatial connectivity of stands to more ancient forests by calculating the cover of broadleaf

117 forests in a circular buffer of 500m radius around each stand (range: 0-30\%). The size of the buffer (78.5

118 ha) has previously been shown to be well-suited for studying plant-herbivore-predator interactions (Barbaro

119 et al., 2014; Chaplin-Kramer et al., 2011). Preliminary analyses revealed that the results were qualitatively

120 the same with buffers of 250, 750 and 1000m radius. Habitat mapping was based on aerial photos using

121 QGIS version 2.18.13 (Quantum GIS Development Team, 2017). Stand size and connectivity were not 122 correlated (Fig. A1; Pearson $r=0.39, P=0.11$ ).

\section{Leaf insect herbivory}

124 In early June 2017, we haphazardly selected four adult oak trees in each forest stand for assessing herbivory

125 and avian predation. On each tree, we haphazardly cut two south facing and two north facing branches,

126 respectively, at 4 and $8 \mathrm{~m}$ height and haphazardly sampled 20 fully developed leaves from each branch

127 (summing 80 leaves per tree and 320 per stand). Leaves were taken to the laboratory for counting the number

128 of leaf mines and galls per leaf and for estimating the percentage of leaf surface consumed or scratched by

129 chewing and skeletonizing herbivores. A previous study (Giffard et al., 2012) had shown that the most

130 common chewers and skeletonizers in the study area are Lepidoptera and Hymenoptera (sawfly) larvae. We

131 distinguished eight levels of surface damage $(0 \%, 1-5 \%, 6-10 \%, 11-15 \%, 16-25 \%, 26-50 \%, 51-75 \%$,

132 and $>76 \%$ ). The gall records were finally discarded from the study because they were too infrequent for

133 independent analyses. In the following, we will refer to 'herbivory' as the tree level average leaf area

134 removed by chewing or skeletonizing invertebrates, and to 'number of mines' as the average number of

135 mines per leaf. We used the number of mines instead of the proportion of leaves with mines as $9 \%$ of leaves

136 had more than one mine. 


\section{Avian predation}

138 We used dummy caterpillars made of plasticine (Staedler, Noris Club 8421, green[5]) to estimate predation 139 on insect herbivores. Although not representative of absolute predation rates in the wild, this method allows

140 to compare relative avian predation across stands (González-Gómez et al., 2006; Gunnarsson et al., 2018;

141 Lövei and Ferrante, 2017). Plasticine caterpillars were $30 \times 3 \mathrm{~mm}$ and light green to mimic late-instar larvae

142 of caterpillars commonly found on oak in the field (Barbaro et al., 2014). We secured 10 plasticine 143 caterpillars at 1.5-2 m height in the canopy of each of our four experimental trees per stand using $0.5 \mathrm{~mm}$

144 metal wires. Predation on plasticine caterpillars was surveyed every six to eight days from 15th May to 15th

145 June (Low et al., 2014). Previous studies have shown that this time period matches the peak activity of 146 insectivorous birds in the study area and is therefore relevant to quantify variation in avian predation

147 (Barbaro et al., 2014; Bereczki et al., 2014; Castagneyrol et al., 2017). All caterpillars with beak marks left

148 by insectivorous birds were recorded and replaced with undamaged ones during each survey. We decided to

149 discard marks putatively left by insectivorous arthropods because we did not assess insectivorous arthropod 150 communities of the stands (see below for birds). Previous to statistical analysis, we standardized our 151 observation by calculating the mean daily predator activity per tree.

\section{Bird communities}

153 We surveyed the insectivorous bird community in each forest stand using 10-min point counts. Censuses 154 were performed by a trained observer between 6:00 and 9:00 a.m. from the centre of the stand. Each stand 155 was censused twice, once between 26th May and 2nd June and a second time between 21th and 29th June 156 during the exposure period of plasticine caterpillars. All birds within the stand were recorded. Further 157 analysis considered only those species that have a predominantly insectivorous diet during the breeding 158 season. We used the highest count of a given species during any of the censuses as estimate of its abundance 159 within the stand.

\section{Data analysis}

161 We built three types of models for our different response variables. First, we used linear mixed-effect models 162 (LMM) to model either insect herbivory or the number of mines as a function of stand size ('Size'), stand 163 connectivity in the surrounding landscape ('Connectivity') and their interaction ('Size $\times$ Connectivity'). 164 Size, Connectivity and Size $\times$ Connectivity were included as fixed effects and the identity of the stand as a 165 random factor. With these predictors three different models were built, each with one further fixed effect, to 166 assess the influence of insectivorous birds on herbivory. These additional fixed effects were either predation 
167 on plasticine caterpillars (measured experimentally) or the abundance or species richness of insectivorous

168 birds in the stand (recorded during point counts). We analysed these effects separately because of their non-

169 independence. Second, we modelled predation on plasticine caterpillars as a function of stand size, stand

170 connectivity and their interaction. All were included as fixed effects and stand identity as random effect.

171 Adopting the same approach as for herbivory and the number of mines, we built three models with either

172 herbivory or the abundance or species richness of insectivorous birds per stand as additional fixed effect.

173 Third, we built a generalised linear model (GLM) with stands as replicates to assess the effect of stand size,

174 connectivity and their interaction on the abundance and richness of insectivorous birds. We used Quasi-

175 poisson and Poisson error distributions to model bird abundance and bird species richness, respectively.

176 All continuous predictor variables were scaled and centred prior to modelling to make their coefficients 177 comparable (Schielzeth, 2010). We first built a full model including all fixed effects, interactions and 178 random factors. Then we applied model simplification by sequentially removing non-significant fixed 179 effects, starting with the least significant interaction. We stopped model simplification with the minimum 180 adequate model when all non-significant terms were taken out. Hereafter, we only report statistics for the 181 simplified models. We estimated and compared model fit by calculating marginal and conditional $\mathrm{R}^{2}$ 182 (respectively $\mathrm{R}_{\mathrm{m}}{ }^{2}$ and $\mathrm{R}_{\mathrm{c}}{ }^{2}$ ) in order to estimate the proportion of variance explained by fixed $\left(\mathrm{R}_{\mathrm{m}}{ }^{2}\right.$ ) and fixed 183 plus random factors $\left(\mathrm{R}_{\mathrm{c}}{ }^{2}\right)$ (Nakagawa and Schielzeth, 2013).

184 All analyses were done in $\mathrm{R}$ version 3.4.1 (2018), using the following packages: car, doBy, forecast,

185 lmerTest, MuMIn and vegan (Barton, 2018; Fox and Weisberg, 2011; Højsgaard and Halekoh, 2018;

186 Hyndman et al., 2018; Kuznetsova et al., 2017; Oksanen et al., 2018).

\section{Results}

188 Insect herbivory was on average $( \pm \mathrm{se}, \mathrm{n}=72) 8.02 \pm 4.51 \%$ (Table A1). The effect of stand size on 189 herbivory depended on the connectivity of the stand (significant Size $\times$ Connectivity interaction, Table 1):

190 herbivory tended to increase with stand size in landscapes with a low stand connectivity whereas it decreased

191 in landscape where broadleaf forests where more abundant (Fig. 1). Neither avian predation on plasticine 192 caterpillars nor bird abundance or richness had a significant effect on herbivory. The number of mines per 193 leaf was on average $0.07 \pm 0.05$ (Table A1) and decreased in stands that were more connected. Leaf miners 194 were not affected by stand size (Table 1 ). 
195 A total of 18 caterpillars out of the 720 exposed (2.5\%) presented marks of bird attacks. Avian predation

196 slightly increased with stand size while it did not vary with stand connectivity or the abundance or richness

197 of insectivorous birds in the stand (Table 1).

198 We detected a total of 17 bird species within the studied oak stands. The mean $( \pm \mathrm{se}, \mathrm{n}=18)$ abundance

199 was $4.22 \pm 2.59$ individuals (range: 1 - 9) and the mean species richness was $3.22 \pm 1.66$ (range: 1 - 6). The 200 most abundant bird species were blue tit (Cyanistes caeruleus), common chaffinch (Fringilla coelebs) and 201 chiffchaff (Phylloscopus collybita) (Fig. A2). These three species accounted for $38.2 \%$ of all records. Total 202 bird abundance increased with stand size (Fig. 2a, Table 2) and decreased with stand connectivity (Fig. 2b,

203 Table 2). The strength of stand size and connectivity effects was comparable although their effects were 204 opposite. Species richness did not vary with stand size nor with stand connectivity.

\section{Discussion}

206 Our study revealed that the size and connectivity of novel native forest stands affect herbivorous insects and 207 insectivorous birds in different ways. While the abundance of leaf miners depended on stand connectivity 208 alone, herbivory by chewers and skeletonizers was influenced by an interplay between stand size and 209 connectivity, and bird abundance (but not species richness) showed consistent independent and opposite 210 responses to stand size and connectivity. This divergence of relationships is likely to arise from differences 211 in the spatial grain of habitat perception and use by the different trophic guilds. It illustrates the complex 212 nature of trophic cascades involving trees, insect herbivores and insectivorous birds in novel native forest 213 stands (Gripenberg and Roslin, 2007).

\section{Insect herbivores}

215 The observed decrease in the abundance of leaf mining insects with increasing stand connectivity contrasts 216 with previous detailed studies of leaf miners on Quercus robur (Gripenberg et al., 2008; Tack et al., 2010) 217 that reported the opposite trend. Importantly, however, these studies focused on a finer spatial grain since 218 they compared individual oak trees with different small-scale ecological neighbourhoods, not with entire 219 forest stands. While the context of their study implies limited movement ranges of leaf mining insects, our 220 results suggest that low abundance of source populations in the surroundings does not limit the ability of 221 this guild to colonise and persist in small novel forest stands. The observed trend could instead be triggered 222 by a resource dilution effect (Otway et al., 2005) whereby herbivore concentrate on the fewer available host 223 individuals (Bañuelos and Kollmann, 2011). Dietary specialists such as many leaf miners should be 224 particularly concerned by resource dilution (Elzinga et al., 2005). 
225 Herbivory by chewing and skeletonizing insects was triggered by stand size in areas where oaks were

226 generally sparse. Positive relationships between stand size and herbivory have also been reported by several

227 studies conducted in considerably larger forest fragments (De La Vega et al., 2012; Simonetti et al., 2007

228 but see Maguire et al., 2015; Silva and Simonetti, 2009). They could arise from a higher density and/or

229 diversity of insect herbivores in larger stands (Chávez-Pesqueira et al., 2015), as predicted by the resource

230 concentration hypothesis (Hambäck and Englund, 2005; Root, 1973). This hypothesis states that the

231 intensity of physical and chemical cues makes these stands more likely to be found and colonised and less

232 likely to be left by herbivores. The resource concentration hypothesis should be particularly relevant in small

233 habitat patches, such as those of our study system. However, we found that leaf herbivory ceased to increase

234 with stand size and started instead to decline when broadleaf forest became more abundant in the

235 surroundings. We have two possible, non-exclusive explanations for this phenomenon: (i) colonization rates

236 of chewers and skeletonizers could generally be so high in our study system that even the smallest forest

237 stands will be effectively reached (and, if necessary, re-colonized) when a certain threshold abundance of

238 suitable habitats and associated herbivore source populations exist in the landscape (Fahrig, 2013). This

239 hypothesis is supported by the fact that novel established forest stands are very rapidly colonised by

240 woodland generalist species (Fuentes-Montemayor et al., 2015; Fuller et al., 2018). Second, (ii) insect

241 herbivory tends to be favoured by edge effects (De Carvalho Guimarães et al., 2014), especially when it

242 involves generalist species (Bagchi et al., 2018). Edge effects decrease in larger stands, which would

243 counteract other positive effects of stand size on herbivory. Both explanations together suggest that the

244 patterns of leaf herbivory that we observed are likely to be primarily driven by a relatively limited set of

245 mobile generalist species. These species generated however leaf consumption rates that were low but

246 comparable to those recorded in many older and larger oak forests (Gunnarsson et al., 2018; Moreira et al.,

247 2018; Sanz, 2001), and they enabled a quick build-up of trophic cascades even in the smallest and youngest

248 stands of our study system (Hagen et al., 2012).

\section{Avian insectivores and insectivory}

250 Overall bird abundance and species richness were rather low as well as the size of the stands compared to 251 previous works conducted in the same area (Barbaro et al., 2005; Giffard et al. 2012), and so was also the 252 rate of avian predation (Castagneyrol et al., 2017). Previous studies by Genua et al. (2017), Peter et al. 253 (2015) and Ruiz-Guerra et al. (2012) also found an increase in bird abundance with an increase in continuous 254 forest in the landscape. These forests were however larger than the stands of our study, supporting the idea 255 that avian predation rate and bird abundance (but not species richness) increased with stand size. Overall, 256 these findings suggest that the activity of insectivorous birds in our study system is constrained by the 257 carrying capacity of their wooded habitats. Typical breeding season territories of the most frequently 
258 recorded bird species actually exceed the size of our smallest stands (Hinsley et al., 1995) and only the

259 largest stands could regularly sustain more than one territory of the same species. These large stands should

260 also provide the broadest range of tree ages and vegetation structures to different species, although it

261 certainly is still inferior to that of mature forests (Fuentes-Montemayor et al., 2015). Habitat diversity and

262 quality might then also be behind our rather surprising finding that bird abundance (although not species

263 richness) tended to decrease with increasing stand connectivity (Fig. 2). Around the least connected stands,

264 the broadleaf forest cover typically consisted of small, early-successional woodland patches, whereas

265 several of the most connected stands were close to more continuous, older forests, expected to host a large

266 functional diversity of insectivorous birds. The habitat quality of our focal stands should hence equal or

267 exceed that of their surroundings in the former case but be inferior in the latter. The lower use of stands

268 located near larger forests could then be interpreted as a resource dilution effect (see also Berg, 1997;

269 Brotons et al., 2003). That we failed to see this landscape-scale effect reflected in our predation experiment

270 could then simply be due to the low overall number of caterpillar attacks that we recorded and/or other

271 potential limitations of the experimental approach (Muchula et al., 2019). It is however consistent with

272 previous studies that fail to correlate herbivory with predation on plasticine caterpillars (Bereczki et al.,

273 2014; Castagneyrol et al., 2017; but see Gunnarsson et al. 2018).

\section{Tree-herbivore-insectivore interactions and the management of novel}

\section{5 native forests}

276 To date most studies on the ecological impacts of active or passive afforestation in fragmented landscapes

277 have focused on patterns of biodiversity (reviewed in Burton et al., 2018), whereas functional ecological

278 aspects have received far less attention (but see Rey Benayas and Bullock, 2012). Our study on bird-insect

279 relationships in novel established native forest stands adds a novel perspective to this field. Taken together,

280 our results indicate that novel forest stands can be very effectively colonised by different guilds of insect

281 herbivores. Although this process is likely to involve primarily a subset of mobile generalist species, these

282 alone can generate levels of herbivory that are quite comparable to those at later stages of forest succession

283 and in areas with higher forest cover. In turn, the build-up of insectivorous bird communities tends to occur

284 more slowly because these depend more than their prey on the development of suitable habitat patches of a

285 certain minimum size (Genua et al., 2017). Birds, as long-lived mobile vertebrate insectivores, typically

286 need to find enough substitutable or non-substitutable resources in the surrounding habitat patches to fulfil

287 entirely their life cycles, namely landscape supplementation and complementation processes (Brotons et al.,

288 2005; Dunning et al., 1992; Fahrig, 2017; Tubelis et al., 2004). Globally, we failed to detect any evidence

289 of top-down control of herbivory by predators. As a consequence, trophic networks in our study system are 
290 likely to underlie strong stochasticity, resulting in extensive among-stand heterogeneity and variation 291 through time, which is also typical of forest ecosystems having experienced long-term fragmentation 292 processes (Hagen et al., 2012; Bregman et al., 2015; Fahrig, 2017).

293 The value of native broadleaf woodlands for biodiversity conservation is important to consider for 294 sustainable forest management in rural landscapes. Landscape defragmentation through networks of novel 295 native forest stands represents a cost-efficient tool for restoring biodiversity and numerous associated 296 ecosystem services (Rey Benayas and Bullock, 2012). Yet the dynamics and ecological functioning of novel 297 native forest stands remain much less well understood than those of forest remnants resulting from 298 fragmentation. Our study underpins that different trophic guilds respond very differently to these novel 299 habitats depending on the spatial grain at which they perceive and exploit them (Gripenberg and Roslin, 300 2007). To favour a rapid build-up of diverse, and hence stable, trophic networks involving insect herbivores 301 and their predators, woodland creation schemes should focus on habitat size and quality rather than 302 connectivity, including a management that facilitates a diverse tree and understorey vegetation structure (see 303 also Burton et al., 2018; Fuller et al., 2018).

\section{Acknowledgements}

305 We thank Christophe Poileux, Victor Rébillard, Fabrice Vetillard and Elias Garrouj for their technical 306 assistance in the field and in the laboratory. We also thank two anonymous reviewers for helpful comments. 307 E.V.C was founded by the project SPONFOREST (grant BIODIVERSA 2015-58).

\section{Author contributions}

309 E.V.C., B.C., A.H and I.V.H conceived the study and acquired the data. E.V.C and B.C analysed the data. 310 E.V.C., B.C and A.H drafted the first version of the manuscript. All authors wrote the final version of the 311 manuscript.

\section{References}

313 Bagchi, R., Brown, L.M., Elphick, C.S., Wagner, D.L., Singer, M.S., 2018. Anthropogenic 314 fragmentation of landscapes: mechanisms for eroding the specificity of plant-herbivore 315 interactions. Oecologia 187, 521-533. https://doi.org/10.1007/s00442-018-4115-5 
316 Bañuelos, M.J., Kollmann, J., 2011. Effects of host-plant population size and plant sex on a specialist leaf-miner. Acta Oecologica 37, 58-64. https://doi.org/10.1016/j.actao.2010.11.007

319 Barbaro, L., Giffard, B., Charbonnier, Y., van Halder, I., Brockerhoff, E.G., 2014. Bird functional diversity enhances insectivory at forest edges: A transcontinental experiment. Divers. Distrib. 20, 149-159. https://doi.org/10.1111/ddi.12132

322 Barthelemy, H., Stark, S., Olofsson, J., 2015. Strong responses of subarctic plant communities to long-term reindeer feces manipulation. Ecosystems 18, 740-751.

324 Barton, K., 2018. MuMIn: Multi-Model Inference.

325 Bereczki, K., Ódor, P., Csóka, G., Mag, Z., Báldi, A., 2014. Effects of forest heterogeneity on the efficiency of caterpillar control service provided by birds in temperate oak forests. For. Ecol. Manage. 327, 96-105. https://doi.org/10.1016/j.foreco.2014.05.001

328 Berg, Å., 1997. Diversity and abundance of birds in relation to forest fragmentation, habitat quality and heterogeneity. Bird Study 44, 355-366. https://doi.org/10.1080/00063659709461071

331 Böhm, S.M., Wells, K., Kalko, E.K. V, 2011. Top-down control of herbivory by birds and bats in the canopy of temperate broad-leaved oaks (Quercus robur). PLoS One 6.

334 Brotons, L., Herrando, S., Martin, J.-L., 2005. Bird assemblages in forest fragments within Mediterranean mosaics created by wild fires. Landsc. Ecol. 19, 663-675. https://doi.org/10.1007/s10980-005-0165-2

337 Brotons, L., Mönkkönen, M., Martin, J.L., 2003. Are Fragments Islands? Landscape Context and Density-Area Relationships in Boreal Forest Birds. Am. Nat. 162, 343-357. https://doi.org/10.1086/376887

340 Burton, V., Moseley, D., Brown, C., Metzger, M.J., Bellamy, P., 2018. Reviewing the evidence 341 base for the effects of woodland expansion on biodiversity and ecosystem services in the 
344 Castagneyrol, B., Bonal, D., Damien, M., Jactel, H., Meredieu, C., Muiruri, E.W., Barbaro, L., 345 2017. Bottom-up and top-down effects of tree species diversity on leaf insect herbivory. Ecol. Evol. 7, 3520-3531. https://doi.org/10.1002/ece3.2950

347 Castagneyrol, B., Jactel, H., Charbonnier, Y., Barbaro, L., Dulaurent-Mercadal, A.M., 2014. Egg mortality in the pine processionary moth: Habitat diversity, microclimate and predation effects. Agric. For. Entomol. 16, 284-292. https://doi.org/10.1111/afe.12056

350 Chaplin-Kramer, R., O’Rourke, M.E., Blitzer, E.J., Kremen, C., 2011. A meta-analysis of crop 351 pest and natural enemy response to landscape complexity. Ecol. Lett. 14, 922-932. https://doi.org/10.1111/j.1461-0248.2011.01642.x

353 Chávez-Pesqueira, M., Carmona, D., Suárez-Montes, P., Núñez-Farfán, J., Aguilar, R., 2015. Synthesizing habitat fragmentation effects on plant-antagonist interactions in a phylogenetic context. Biol. Conserv. 192, 304-314. https://doi.org/10.1016/j.biocon.2015.10.002

356 Cooper, J.K., Li, J., Montagnes, D.J.S., 2012. Intermediate fragmentation per se provides stable predator-prey metapopulation dynamics. Ecol. Lett. 15, 856-863.

359 De Carvalho Guimarães, C.D., Viana, J.P.R., Cornelissen, T., 2014. A Meta-Analysis of the Effects of Fragmentation on Herbivorous Insects. Environ. Entomol. 43, 537-545. https://doi.org/10.1016/j.apcata.2015.08.006

362 De La Vega, X., Grez, A.A., Simonetti, J.A., 2012. Is top-down control by predators driving 363 insect abundance and herbivory rates in fragmented forests? Austral Ecol. 37, 836-844. https://doi.org/10.1111/j.1442-9993.2011.02345.x feeding increased the longevity of two egg parasitoids of the pine processionary moth. J. Appl. Entomol. 135, 184-194. https://doi.org/10.1111/j.1439-0418.2010.01547.x 
Dunning, J.B., Danielson, B.J., Pulliam, H.R., Ecology, I., 1992. Ecological Processes That Affect Populations in Complex Landscapes. Nord. Soc. Oikos 65, 169-175.

Elzinga, J.A., Turin, H., Van Damme, J.M.M., Biere, A., 2005. Plant population size and isolation affect herbivory of Silene latifolia by the specialist herbivore Hadena bicruris and parasitism of the herbivore by parasitoids. Oecologia 144, 416-426. https://doi.org/10.1007/s00442005-0096-2

Ewers, R.M., Didham, R.K., 2006. Confounding factors in the detection of species responses to habitat fragmentation. Biol. Rev. Camb. Philos. Soc. 81, 117-142. https://doi.org/10.1017/S1464793105006949

Fahrig, L., 2017. Ecological Responses to Habitat Fragmentation Per Se. Annu. Rev. Ecol. Evol. Syst. 48, annurev-ecolsys-110316-022612. https://doi.org/10.1146/annurev-ecolsys-110316022612

Fahrig, L., 2013. Rethinking patch size and isolation effects: The habitat amount hypothesis. J. Biogeogr. 40, 1649-1663. https://doi.org/10.1111/jbi.12130

Fischer, J., Lindenmayer, D.B., Manning, A.D., Fischer, J., Lindenmayer, D.B., Manning, A.D., 2006. Biodiversity, ecosystem function resilience : ten guiding principle commodity production landsca. Front. Earth Sci. 4, 80-86.

Forest Europe, 2015. Forest Europe (2015) State of Europe's forests 2015. Ministerial Conference on the Protection of Forests in Europe.: Forest Europe, UNECE and FAO. State of Europe's Forests 2015. Status and Trends in Sustainable Forest Management in Europe, 2015. [WWW Document]. Minist. Conf. Prot. For. Eur. For. Eur. UNECE FAO. URL http://www.foresteurope.org/docs/fullsoef2015.pdf

Fox, J., Weisberg, S., 2011. An \{R\} Companion to Applied Regression, Second. ed. Sage, Thousand Oaks $\{\mathrm{CA}\}$.

Franklin, J.F., 1988. Structural and functional diversity in temperate forests, In Wilson,. ed. Washington. 
394 Fuchs, R., Herold, M., Verburg, P.H., Clevers, J.G.P.W., Eberle, J., 2015. Gross changes in

397 Fuentes-Montemayor, E., Peredo-Alvarez, V.M., Watts, K., Park, K.J., 2015. Are woodland 398 399 400 401 402

403 404 405 406 407 408 409 410 411 412 413

414 415 416 417

418 Gunnarsson, B., Wallin, J., Klingberg, J., 2018. Predation by avian insectivores on caterpillars is 419 linked to leaf damage on oak (Quercus robur). Oecologia 188, 733-741.

420 reconstructions of historic land cover/use for Europe between 1900 and 2010. Glob. Chang. Biol. 21, 299-313. https://doi.org/10.1111/gcb.12714 creation schemes providing suitable resources for biodiversity? Woodland moths as a case study. Biodivers. Conserv. 24, 3049-3070. https://doi.org/10.1007/s10531-015-0997-2

Fuller, L., Fuentes-Montemayor, E., Watts, K., Macgregor, N.A., Bitenc, K., Park, K.J., 2018. Local-scale attributes determine the suitability of woodland creation sites for Diptera. J. Appl. Ecol. 55, 1173-1184. https://doi.org/10.1111/1365-2664.13035

Genua, L., Start, D., Gilbert, B., 2017. Fragment size affects plant herbivory via predator loss Lucy. Oikos 126, 1357-1365. https://doi.org/10.1111/oik.04223

Gerzabek, G., Oddou-Muratorio, S., Hampe, A., 2017. Temporal change and determinants of maternal reproductive success in an expanding oak forest stand. J. Ecol. 105, 39-48. https://doi.org/10.1111/1365-2745.12677

Giffard, B., Corcket, E., Barbaro, L., Jactel, H., 2012. Bird predation enhances tree seedling resistance to insect herbivores in contrasting forest habitats. Oecologia 168, 415-424. https://doi.org/10.1007/s00442-011-2089-7

González-Gómez, P.L., Estades, C.F., Simonetti, J.A., 2006. Strengthened insectivory in a temperate fragmented forest. Oecologia 148, 137-143. https://doi.org/10.1007/s00442-0050338-3

Gripenberg, S., Ovaskainen, O., Morriën, E., Roslin, T., 2008. Spatial population structure of a specialist leaf-mining moth. J. Anim. Ecol. 77, 757-767.

Gripenberg, S., Roslin, T., 2007. Nordic Society Oikos Up or down in Space? Uniting the Bottom-up versus Top-down Paradigm and Spatial Ecology. Oikos 116, 181-188. https://doi.org/10.1007/s00442-018-4234-z 
421 Haddad, N.M., Brudvig, L.A., Clobert, J., Davies, K.F., Gonzalez, A., Holt, R.D., Lovejoy, T.E.,

444 Hyndman, R., Athanasopoulos, G., Bergmeir, C., Caceres, G., Chhay, L., O’Hara-Wild, M., 445 446 Sexton, J.O., Austin, M.P., Collins, C.D., Cook, W.M., Damschen, E.I., Ewers, R.M., Foster, B.L., Jenkins, C.N., King, A.J., Laurance, W.F., Levey, D.J., Margules, C.R., Melbourne, B.A., Nicholls, A.O., Orrock, J.L., Song, D., Townshend, J.R., 2015. Habitat fragmentation and its lasting impact on Earth's ecosystems. Appl. Ecol. 1, 1-9. https://doi.org/10.1126/sciadv.1500052

Hagen, M., Kissling, W.D., Rasmussen, C., Cartensen, D.., Dupont, Y.., Kaiser-Bunbury, C.., O’Gorman, E.., Olesen, J.., De Aguiar, M.A.M., Al., E., 2012. Biodiversity, species interactions and ecological networks in a fragmented world, Advances in ecological research. https://doi.org/10.1016/j.pain.2008.02.025

Hambäck, P.A., Englund, G., 2005. Patch area, population density and the scaling of migration rates: The resource concentration hypothesis revisited. Ecol. Lett. 8, 1057-1065. https://doi.org/10.1111/j.1461-0248.2005.00811.x

Hansen, M.C., Potapov, P. V., Moore, R., Hancher, M., Turubanova, S.A., Tyukavina, A., Thau, D., Stehman, S. V., Goetz, S.J., Loveland, T.R., Kommareddy, A., Egorov, A., Chini, L., Justice, C.O., Townshend, J.R.G., 2013. High-resolution global maps of 21st-century forest cover change. Science (80-. ). 342, 850-853. https://doi.org/10.1126/science.1244693

Hinsley, A.S.A., Bellamy, P.E., Newton, I., Sparks, T.H., 1995. Nordic Society Oikos Habitat and Landscape Factors Influencing the Presence of Individual Breeding Bird Species in Woodland Fragments Published by: Wiley on behalf of Nordic Society Oikos Stable URL : http://www.jstor.org/stable/3677057 Habitat and lands. J. Avian Biol. 26, 94-104.

Højsgaard, S., Halekoh, U., 2018. doBy: Groupwise Statistics, LSmeans, Linear Contrasts, Utilities.

Petropoulos, F., Razbash, S., Wang, E., Yasmeen, F., 2018. \{forecast \}: Forecasting functions for time series and linear models. 
Jackson, S.T., Sax, D.F., 2010. Balancing biodiversity in a changing environment: extinction debt, immigration credit and species turnover. Trends Ecol. Evol. 25, 153-160. https://doi.org/10.1016/j.tree.2009.10.001

Kuznetsova, A., Brockhoff, P.B., Christensen, R.H.B., 2017. \{lmerTest $\}$ Package: Tests in Linear Mixed Effects Models. J. Stat. Softw. 82, 1-26. https://doi.org/10.18637/jss.v082.i13

Letourneau, D.K., Jedlicka, J.A., Bothwell, S.G., Moreno, C.R., 2009. Effects of Natural Enemy Biodiversity on the Suppression of Arthropod Herbivores in Terrestrial Ecosystems. Annu. Rev. Ecol. Evol. Syst. 40, 573-592. https://doi.org/10.1146/annurev.ecolsys.110308.120320

Lindenmayer, D.B., Fisher, J., 2013. Habitat fragmentation and landscape change: an ecological and conservation synthesis.

Lövei, G.L., Ferrante, M., 2017. A review of the sentinel prey method as a way of quantifying invertebrate predation under field conditions. Insect Sci. 24, 528-542. https://doi.org/10.1111/1744-7917.12405

Low, P.A., Sam, K., McArthur, C., Posa, M.R.C., Hochuli, D.F., 2014. Determining predator identity from attack marks left in model caterpillars: Guidelines for best practice. Entomol. Exp. Appl. 152, 120-126. https://doi.org/10.1111/eea.12207

Maguire, D.Y., Nicole, T., Buddle, C.M., Bennett, E.M., 2015. Effect of fragmentation on predation pressure of insect herbivores in a north temperate deciduous forest ecosystem. Ecol. Entomol. 40, 182-186. https://doi.org/10.1111/een.12166

Moreira, X., Abdala-Roberts, L., Berny Mier y Teran, J.C., Covelo, F., de la Mata, R., Francisco, M., Hardwick, B., Pires, R.M., Roslin, T., Schigel, D.S., ten Hoopen, J.P.J.G., Timmermans, B.G.H., van Dijk, L.J.A., Castagneyrol, B., Tack, A.J.M., 2018. Impacts of urbanization on insect herbivory and plant defences in oak trees. Oikos 113-123. https://doi.org/10.1111/oik.05497

Muchula, K., Xie, G., Gurr, G.M., 2019. Ambient temperature affects the utility of plasticine caterpillar models as a tool to measure activity of predators across latitudinal and elevational gradients. Biol. Control 129, 12-17. https://doi.org/10.1016/j.biocontrol.2018.11.006 
474 Nakagawa, S., Schielzeth, H., 2013. A general and simple method for obtaining R2 from

475 generalized linear mixed-effects models. Methods Ecol. Evol. 4, 133-142.

476 https://doi.org/10.1111/j.2041-210x.2012.00261.x

477 O'Rourke, M.E., Petersen, M.J., 2017. Extending the 'resource concentration hypothesis' to the 478 landscape-scale by considering dispersal mortality and fitness costs. Agric. Ecosyst.

479 Environ. 249, 1-3. https://doi.org/10.1016/j.agee.2017.07.022

480 Oksanen, J., Blanchet, F.G., Friendly, M., Kindt, R., Legendre, P., McGlinn, D., Minchin, P.R., 481 O’Hara, R.B., Simpson, G.L., Solymos, P., Stevens, M.H.H., Szoecs, E., Wagner, H., 2018. 482 vegan: Community Ecology Package.

483 Otway, S.J., Hector, A., Lawton, J.H., 2005. Resource dilution effects on specialist insect 484 herbivores in a grassland biodiversity experiment. J. Anim. Ecol. 74, 234-240.

485 https://doi.org/10.1111/j.1365-2656.2004.00913.x

486 Peter, F., Berens, D.G., Grieve, G.R., Farwig, N., 2015. Forest Fragmentation Drives the Loss of 487 Insectivorous Birds and an Associated Increase in Herbivory. Biotropica 47, 626-635.

488 https://doi.org/10.1111/btp.12239

489 Quantum GIS Development Team, 2017 [WWW Document], n.d. URL http://qgis.org (accessed $490 \quad 1.4 .17)$.

491 R Core Team, 2018. R: A Language and Environment for Statistical Computing.

492 Rey Benayas, J.M., Bullock, J.M., 2012. Restoration of Biodiversity and Ecosystem Services on 493 Agricultural Land. Ecosystems 15, 883-899. https://doi.org/10.1007/s10021-012-9552-0

494 Rey Benayas, J.M., Bullock, J.M., Newton, A.C., 2008. Creating woodland islets to reconcile 495 ecological restoration, conservation, and agricultural land use. Front. Ecol. Environ. 6, 329496 336. https://doi.org/10.1890/070057

497 Root, R.B., 1973. Organization of a plant-arthropod association in simple and diverse habitats: 498 the fauna of collards (Brassica oleracea). Ecol. Monogr. 43, 95-124. 
499 Rosenheim, J.A., 1998. Higher-Order Predators and the Regulation of Insect Herbivore

500 Populations. Annu. Rev. Entomol. 43, 421-447.

$501 \quad$ https://doi.org/10.1146/annurev.ento.43.1.421

502 Rossetti, M.R., González, E., Salvo, A., Valladares, G., 2014. Not all in the same boat: trends and 503 mechanisms in herbivory responses to forest fragmentation differ among insect guilds.

504 Arthropod. Plant. Interact. 8, 593-603. https://doi.org/10.1007/s11829-014-9342-z

505 Rossetti, M.R., Tscharntke, T., Aguilar, R., Batáry, P., 2017. Responses of insect herbivores and 506 herbivory to habitat fragmentation: a hierarchical meta-analysis. Ecol. Lett. 20, 264-272.

507 https://doi.org/10.1111/ele.12723

508 Ruiz-Guerra, B., Renton, K., Dirzo, R., 2012. Consequences of Fragmentation of Tropical Moist 509 Forest for Birds and Their Role in Predation of Herbivorous Insects. Biotropica 44, 228510 236. https://doi.org/10.1111/j.1744-7429.2011.00795.x

511 Sanz, J.J., 2001. Experimentally increased insectivorous bird density results in a reduction of 512 caterpillar density and leaf damage to Pyrenean oak. Ecol. Res. 16, 387-394. https://doi.org/10.1046/j.1440-1703.2001.00403.x

514 Schielzeth, H., 2010. Simple means to improve the interpretability of regression coefficients. Methods Ecol. Evol. 1, 103-113. https://doi.org/10.1111/j.2041-210x.2010.00012.x

516 Schröter, D., Cramer, W., Leeman, R., Prentice, I.C., Araujo, M.., Arnell, N.W., Bondeau, A., Bugmann, H., Al., E., 2005. Ecosystem Service Supply and Vulnerability to Global Change in Europe. Science (80-. ). 5752, 1333-1338. https://doi.org/10.1126/science.1115233

519 Sezen, U.U., Chazdon, R.L., Holsinger, K.E., Rica, C., 2005. Genetic Consequences of Tropical. 520 Science (80-. ). 2005. https://doi.org/10.1126/science.1105034

521 Silva, C.A., Simonetti, J.A., 2009. Inquiring into the causes of depressed folivory in a fragmented 522 temperate forest. Acta Oecologica 35, 458-461. https://doi.org/10.1016/j.actao.2009.01.001

523 Simonetti, J.A., Grez, A.A., Celis-Diez, J.L., Bustamante, R.O., 2007. Herbivory and seedling 524 performance in a fragmented temperate forest of Chile. Acta Oecologica 32, 312-318. 525 https://doi.org/10.1016/j.actao.2007.06.001 
526 Storch, D., 1998. Densities and territory sizes of birds in two different lowland communities in 527 eastern Bohemia. Folia Zool. 47, 181-188.

528 Tack, A.J.M., Ovaskainen, O., Pulkkinen, P., Roslin, T., 2010. Spatial location dominates over

529 host plant genotype in structuring an herbivore community Published by : Ecological

530 Society of America Linked references are available on JSTOR for this article : Your use of

531 the JSTOR archive indicates your acceptance of $\mathrm{t} 91,2660-2672$.

$532 \quad$ https://doi.org/10.1890/09-1027.1

533 Tubelis, D.P., Cowling, A., Donnelly, C., 2004. Landscape supplementation in adjacent savannas 534 and its implications for the design of corridors for forest birds in the central Cerrado, Brazil. 535 Biol. Conserv. 118, 353-364. https://doi.org/10.1016/j.biocon.2003.09.014

536 Van Dorp, D. Van, Opdam, P.F.M., 1987. Effects of patch size, isolation and regional abundance 537 on forest bird communities 1, 59-73.

538 Whytock, R.C., Fuentes-Montemayor, E., Watts, K., Barbosa De Andrade, P., Whytock, R.T.,

539 French, P., Macgregor, N.A., Park, K.J., 2018. Bird-community responses to habitat creation 540 in a long-term, large-scale natural experiment. Conserv. Biol. 32, 345-354.

541 https://doi.org/10.1111/cobi.12983

542

543

544

545

546

547

548 


\section{Figure captions}

550 Fig. 1. Interactive effect of stand size and connectivity on herbivory. White to black colour scale 551 and isolines show the predicted percentage of herbivory along standardized gradients of stand size 552 (measured as the stand area) and stand connectivity (measured as the cover of broadleaf forest 553 within a buffer of $500 \mathrm{~m}$ radius). White dots show the distribution of the original data.

554 Fig. 2: Effects of stand size and connectivity on bird abundance (a, b). Dots represent the individual 555 stands. Solid lines and dashed lines represent model predictions and corresponding standard errors, 556 respectively.

557

558

559

560

561

562

563

564

565

566

567

568

569

570

571

572

573 
574 Fig. 1

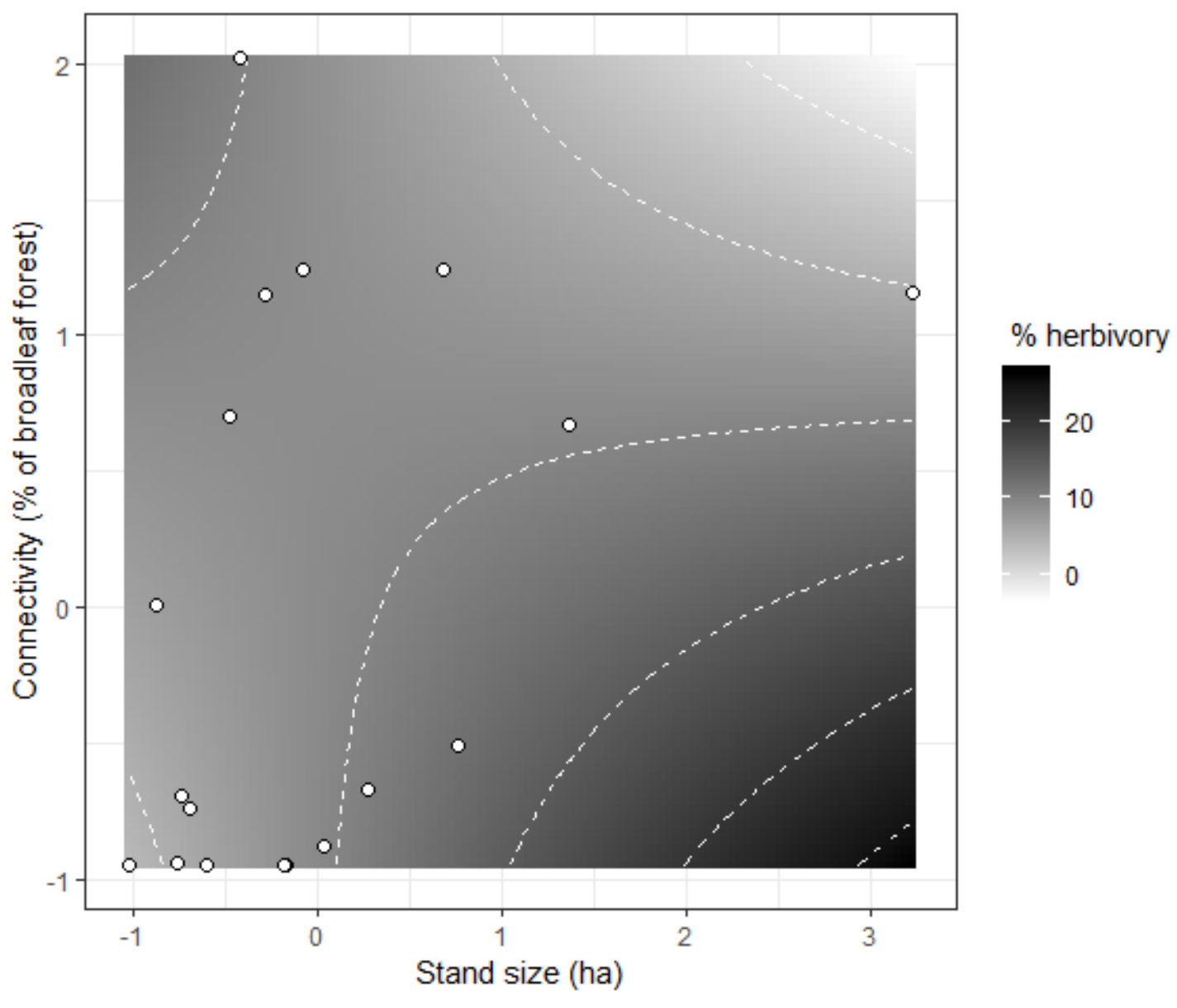

575

576

577

578

579

580

581

582

583

584 
585 Fig. 2
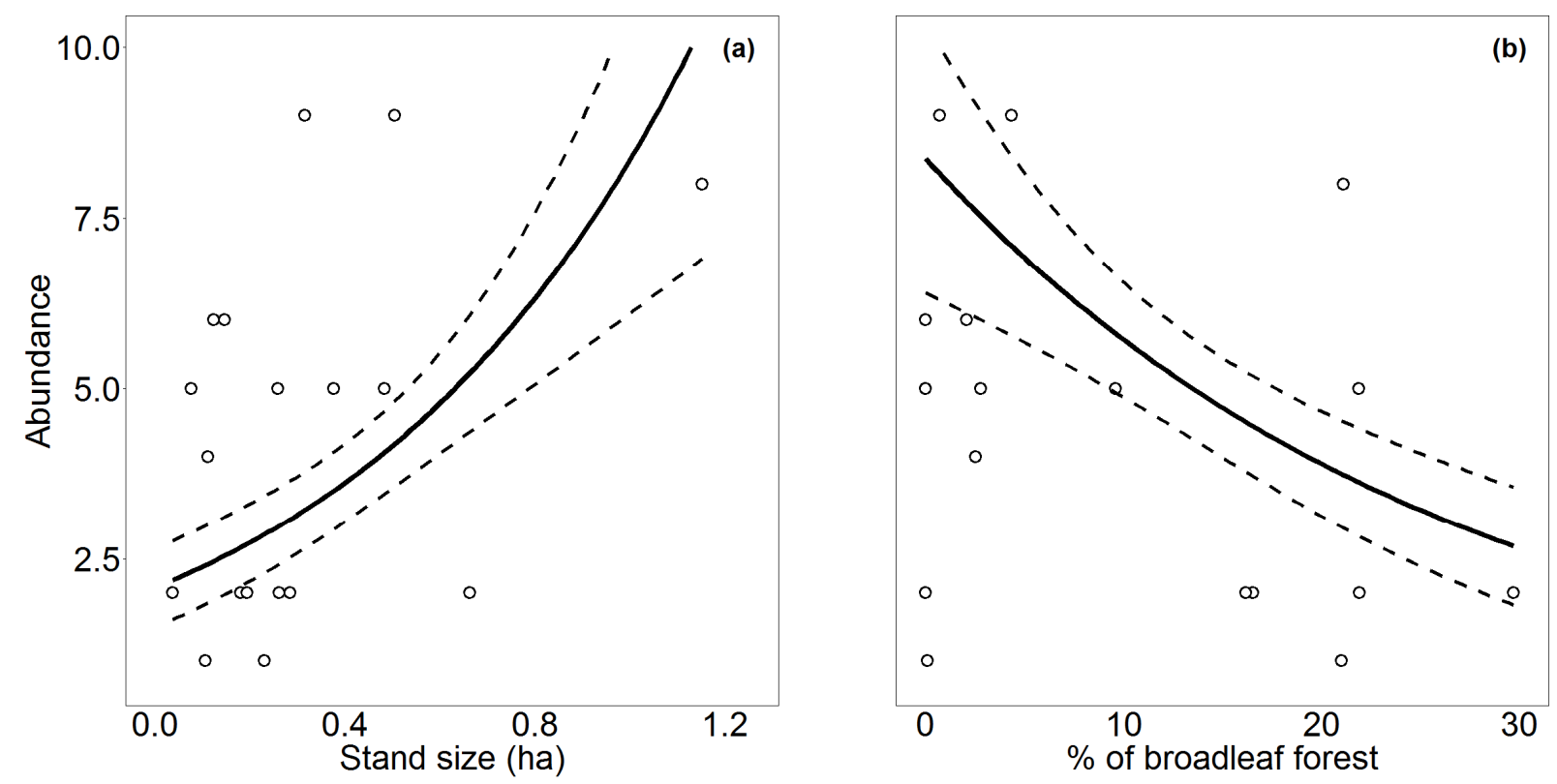

587

588

589

590

591

592

593

594

595

596

597

598

599 
600 Table 1. Summary of LMM testing the effect of stand size, connectivity, their interaction and either

601 Avian predation, abundance or richness on insect herbivory. For avian predation the effect of stand 602 size, connectivity, their interaction and either herbivory, bird abundance or richness were tested. 603 Significant variables are indicated in bold. Only predictors retained after model simplification are 604 shown. Predictors were scaled and centred. $R^{2} m$ and $R^{2} c$ correspond to the variance explained by 605 fixed and fixed plus random factors, respectively.

606

607

\begin{tabular}{|l|l|l|l|l|l|l|}
\hline Response & Predictors & $\boldsymbol{x}^{\mathbf{2}}$ & $\mathbf{D f}$ & $\mathbf{C o e f} \pm \mathbf{S E}$ & $\boldsymbol{P}$ & \multirow{2}{*}{$\mathbf{R}_{\mathbf{m}}\left(\boldsymbol{R}^{\mathbf{2}} \mathbf{c}\right)$} \\
\hline \multirow{3}{*}{ Herbivory } & Size & 0.06 & 1 & $2.010 \pm 1.061$ & 0.807 & \multirow{2}{*}{$0.20(0.43)$} \\
\cline { 2 - 7 } & Connectivity & 0.87 & 1 & $-0.041 \pm 0.784$ & 0.351 & \\
\cline { 2 - 7 } & Size $\times$ Connectivity & 8.35 & 1 & $-2.933 \pm 1.015$ & $\mathbf{0 . 0 0 4}$ & \\
\hline No. of mines & Connectivity & 4.53 & 1 & $-0.016 \pm 0.007$ & $\mathbf{0 . 0 3 3}$ & $0.10(0.31)$ \\
\hline Avian predation & Size & 3.94 & 1 & $0.135 \pm 0.068$ & $\mathbf{0 . 0 4 7}$ & $0.06(0.13)$ \\
\hline
\end{tabular}

608 Table 2. Summary of the GLM on insectivorous bird abundance and species richness as a function 609 of stand size and connectivity. Only predictors remaining after model simplification are shown. 610 Stand size and connectivity were previously standardized. LR: Likelihood Ratio.

611

\begin{tabular}{|l|l|l|l|l|l|l|}
\hline Response & Predictors & $\chi^{\mathbf{2}}$ & Df & Coef. \pm SE & $\boldsymbol{P}$ & $\boldsymbol{R}^{\mathbf{2}} \mathbf{( R}^{\mathbf{2}} \mathbf{c}$ \\
\hline \multirow{3}{*}{ Bird abundance } & Size & 8.569 & 1 & $\begin{array}{l}0.373 \pm \\
0.124\end{array}$ & $\mathbf{0 . 0 0 3}$ & \multirow{2}{*}{$0.42(0.43)$} \\
\cline { 2 - 6 } & Connectivity & 6.554 & 1 & $\begin{array}{l}-0.391 \pm \\
0.164\end{array}$ & $\mathbf{0 . 0 1 0}$ & \\
\hline
\end{tabular}


612 Appendix A

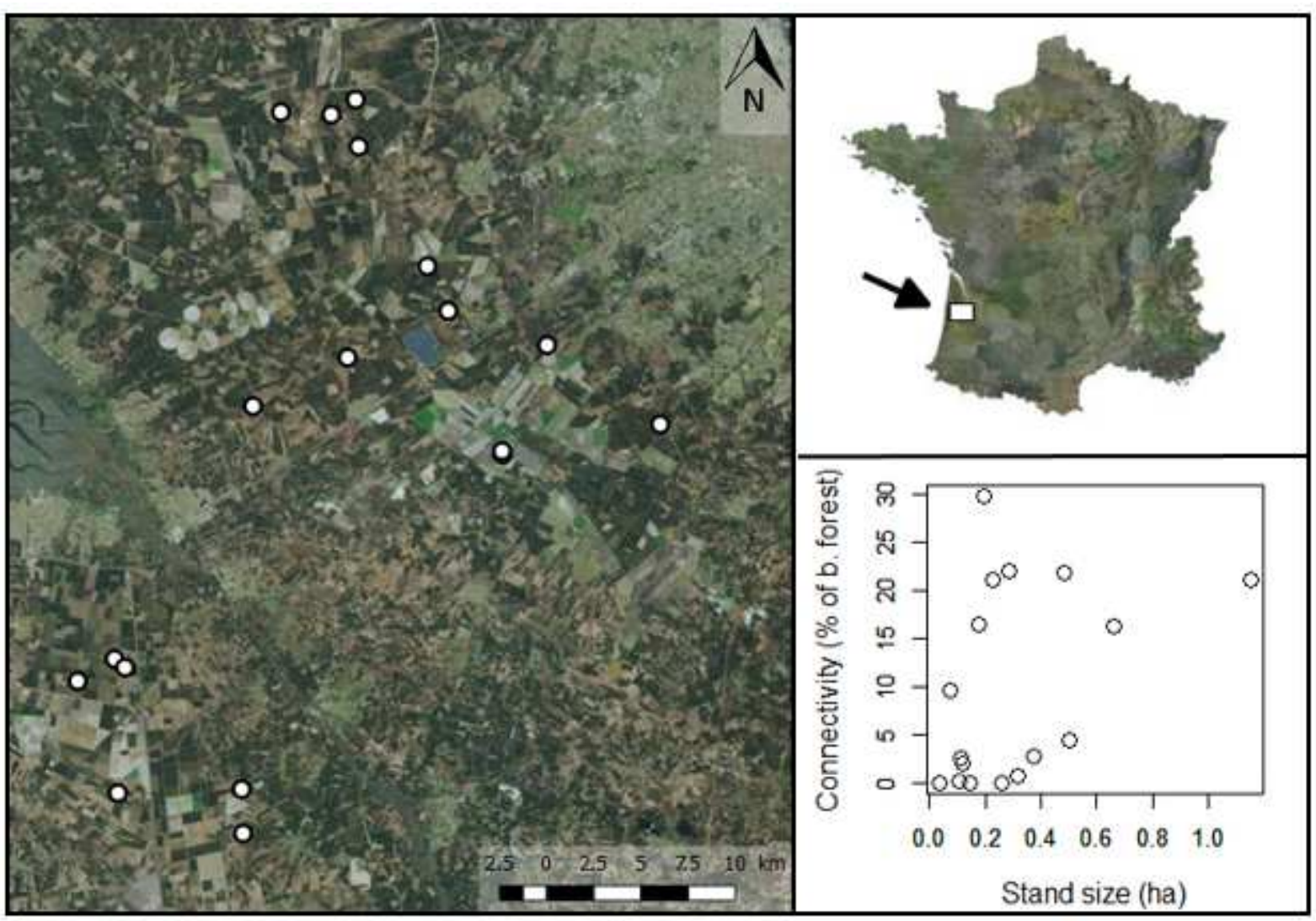

613

614

615 Fig. A1. Location map of the study area in the Aquitaine region, south-western France, showing 616 the 18 oak stands at the top right and left of the figure, and figure showing stand size (ha) and 617 connectivity of each stand at the bottom right of the figure.

618

619

620

621

622 
623 Table A1. Information about the location and size of the oak stands included in the study and 624 summary of the results of herbivory (\% leaf damage and Number of mines), predation on plasticine 625 caterpillars and bird abundance and species richness within each stand.

626

\begin{tabular}{|c|c|c|c|c|c|c|c|c|c|}
\hline Stand & Latitude & Longitude & $\begin{array}{l}\text { Stand } \\
\text { size } \\
\text { (ha) }\end{array}$ & $\begin{array}{l}\text { No. of } \\
\text { Oaks }\end{array}$ & Herbivory & $\begin{array}{c}\text { No. of } \\
\text { mines / } \\
\text { leaf }\end{array}$ & $\begin{array}{c}\text { Avian } \\
\text { predation on } \\
\text { caterpillars }\end{array}$ & $\begin{array}{c}\text { Bird } \\
\text { abundance }\end{array}$ & $\begin{array}{c}\text { Bird } \\
\text { species } \\
\text { richness }\end{array}$ \\
\hline 1 & 44.743 & -0.800 & 0.375 & 110 & 13.88 & 0.147 & 0.589 & 5 & 4 \\
\hline 2 & 44.729 & -0.733 & 0.123 & 28 & 4.68 & 0.078 & 0.089 & 6 & 4 \\
\hline 3 & 44.764 & -0.816 & 0.179 & 35 & 13.72 & 0.056 & 0.000 & 2 & 1 \\
\hline 4 & 44.568 & -1.011 & 0.315 & 50 & 4.41 & 0.069 & 0.268 & 9 & 6 \\
\hline 5 & 44.564 & -1.004 & 0.111 & 32 & 6.58 & 0.050 & 0.000 & 4 & 3 \\
\hline 6 & 44.556 & -0.035 & 0.106 & 30 & 6.50 & 0.059 & 0.268 & 1 & 1 \\
\hline 7 & 44.834 & -0.919 & 0.504 & 33 & 13.77 & 0.025 & 0.324 & 9 & 6 \\
\hline 8 & 44.834 & -0.885 & 0.229 & 71 & 5.81 & 0.044 & 0.893 & 1 & 1 \\
\hline 9 & 44.842 & -0.869 & 0.663 & 132 & 6.54 & 0.034 & 0.491 & 2 & 2 \\
\hline 10 & 44.819 & -0.865 & 0.483 & 150 & 4.92 & 0.056 & 0.000 & 5 & 4 \\
\hline 11 & 44.677 & -0.760 & 0.261 & 55 & 7.31 & 0.141 & 0.263 & 2 & 2 \\
\hline 12 & 44.675 & -0.759 & 0.036 & 17 & 5.58 & 0.103 & 0.781 & 2 & 2 \\
\hline 13 & 44.693 & -0.655 & 0.146 & 64 & 3.97 & 0.072 & 0.179 & 6 & 4 \\
\hline 14 & 44.504 & -0.004 & 0.193 & 43 & 10.55 & 0.022 & 0.179 & 2 & 2 \\
\hline 15 & 44.692 & -0.928 & 1.151 & 156 & 6.35 & 0.088 & 0.964 & 8 & 6 \\
\hline 16 & 44.719 & -0.869 & 0.283 & 29 & 11.65 & 0.066 & 0.536 & 2 & 2 \\
\hline 17 & 44.509 & -0.922 & 0.075 & 16 & 8.78 & 0.072 & 0.089 & 5 & 4 \\
\hline 18 & 44.487 & -0.920 & 0.258 & 38 & 9.40 & 0.075 & 0.655 & 5 & 4 \\
\hline
\end{tabular}

627

628

629

630

631

632

633 
634 Fig. A2. Proportion of the total abundance of each insectivorous bird species recorded during the 635 study. The total number of individuals per species is indicated on each bar.

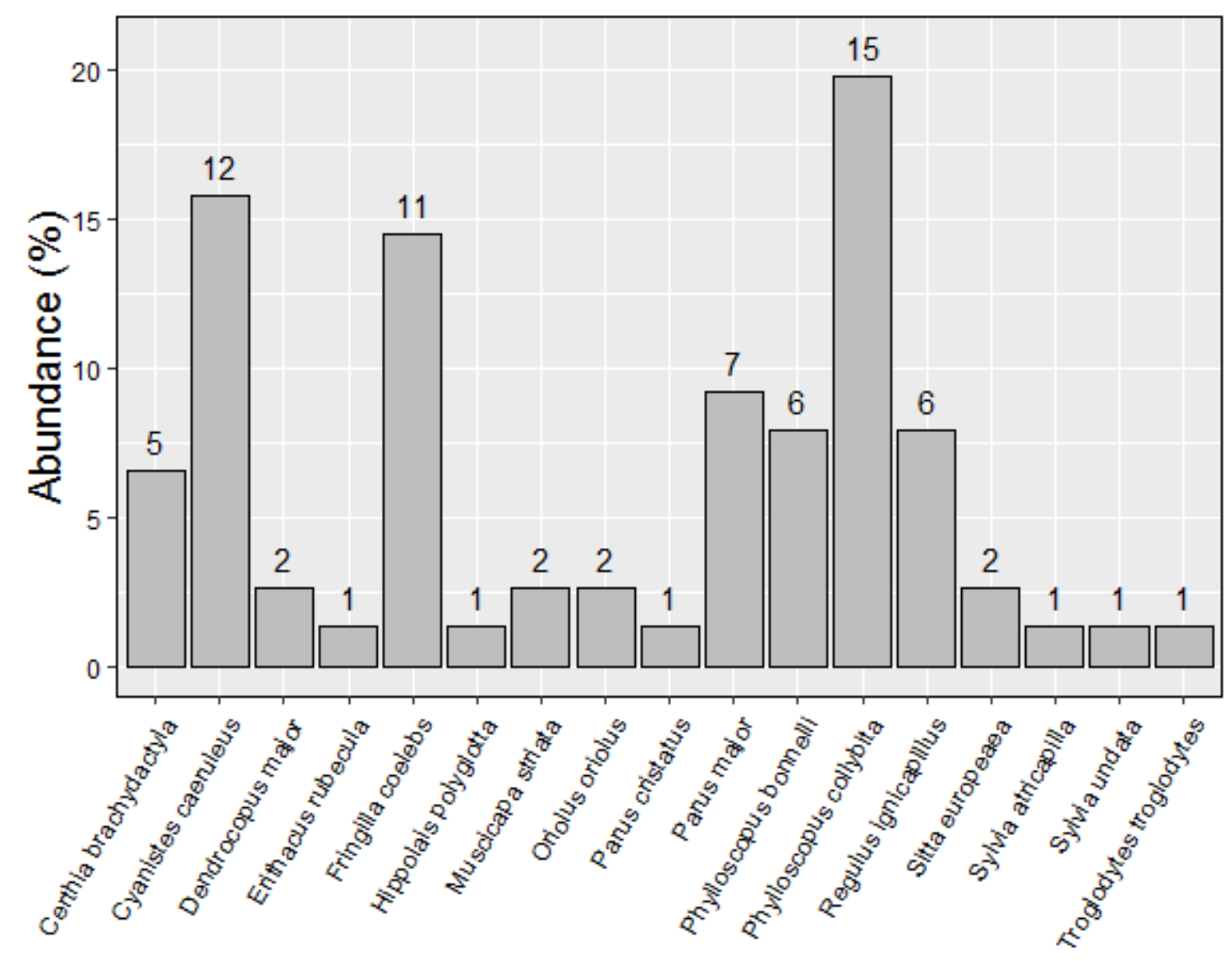

